\title{
THE INSTITUTE OF BIOLOGY
}

T HE tenth anniversary of the foundation of the Institute of Biology was celebrated by a dinner held in the restaurant of the Zoological Society of London on January 8, 1960.

It may be recalled that the first general meeting of the Institute was held at King's College, London, on January 5, 1950, when more than 150 biologists were present, representing most branches of the subject. This meeting, however, was only a culmination of more than three years activity (see Nature, 168,131 ; 1951). A council of fourteen members was elected, with Dr. E. Hindle as president, Prof. J. F. Danielli as honorary secretary, and Dr. R. J. C. Harris as honorary treasurer. Rules of membership were drawn up, and an office was established in the British Medical Association House, Tavistock Square, with a general secretary and staff. The membership reached about 500 by the end of the year and has steadily increased so that by the end of 1959 it numbered 2,250 , with 260 overseas members.

Each year the Institute has held a symposium on some subject of general biological interest and published the papers and discussions. The first symposium in 1950 was on "Biological Hazards of Atomic Energy", and the topic for 1960 was "Biology of Space Travel". Freezing and drying, biology of deserts, biology of the sea, numbers of man and animals, biological aspects of the transmission of disease, the biology of ageing, the biological productivity of Britain, the effects of pollution on living material, and problems arising from the control of pests and diseases indicate the wide range of topics which have been discussed at successive meetings; and the records of these symposia are of considerable value to students in these respective fields.

The Institute's widening activities necessitated larger premises, and in 1955 a move was made to the present quarters at 41 Queen's Gate, London, S.W.7. At the same time, nine local branches have been founded: six in Britain, one in Northern Ireland, another in Eire, and one in Malaya. These local branches hold meetings independently of the central organization.

The Institute represents the views of biologists on various national and local bodies concerned with technical education, and played an active part in promoting the scheme for endorsed certificates, which is now firmly established with courses in some dozen centres. The Ministry of Education has now joined the Institute in endorsing certificates; and the Scottish Education Department, with the co-operation of the Institute of Biology, has instituter a National Certificate in Biology.

The Institute publishes a quarterly journal containing news of general interest to biologists, as well as articles on broad topics and book reviews. One of its publications, "Biology as a Career", is now in its third edition; in addition, advice on this subject is given to student members, parents, youth advisory officers and teachers. Also two surveys on salaries were undertaken, during 1953 and 1956.

The Institute maintains an appointments register for the use of members seeking advice on potential employers and vacancies, a service of especial value to overseas members. It also publishes a list of fulltime consultants on biological subjects, including a list of topics for which the services of occasional consultants can be obtained. The Institute also maintains an information service for the use of members, Government departments, firms and the general public, and is consulted on a wide range of biological subjects.

On various occasions the Council of the Institute has made representations of their views to various Ministers of State on matters affecting the development of biological research. Through the medium of the Parliamentary and Scientific Committee, assistance is given to keep members of Parliament informed of the biological background to such problems as food supplies, ageing, Colonial research, pollution, etc.

The officers of the Institute have been selected with the object of obtaining as wide a representation as possible of the various branches of the subject. The office of president, restricted to two years duration. has been held successively by Dr. E. Hindle, Prof. F. E. Fritsch, Sir James Gray, Prof. W. H. Pearsall and Dr. A. S. Parkes. The honorary secretaries have been Prof. J. F. Danielli, Dr. G. E. Fogg and Mr. H. J. Bunker ; and honorary treasurers, Dr. R. J. C. Harris, Dr. N. E. Hickin and Mr. W. V. Harris. The general secretary, Mr. D. J. B. Copp, has served the Institute since 1951, having previously been assistantsecretary of the British Association.

\section{NUCLEAR SCIENCE IN THE MIDDLE EAST}

T $\mathbf{T}$ might be thought a bold experiment to hold $a_{0}$ nuclear science conference in an area which is only just beginning to make progress in this field; never. theless, the symposium held in Hamadan during July 6-18 was an undoubted success.

The symposium was organized by the CENTO (Central Treaty Organization) Institute of Nuclear Science in Tehran (see Nature, 186, $513 ; 1960$ ), and all ten of its scientific staff took part. The total number of participants was about sixty, as follows :

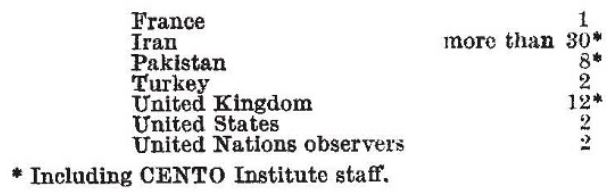

The French and United Nations participants were experts on various missions in Iran. Delegates' expenses were met from CENTO funds, from the 
funds of the Governments concerned, and from other sources.

The symposium was opened by Dr. T. Ziai (UnderSecretary, Ministry of Industries and Mines) on behalf of the Iranian Government, and by the Governor of Hamadan. Thereafter there were nineteen working sessions, including four general discussions, on a wide range of nuclear science topics. The proceedings were informal, and no record was kept; this no doubt contributed to the freedom and liveliness of discussion.

Perhaps the most valuable feature of the symposium was its impact on the nuclear science policies of the CENTO countries. To this end, many of the papers took the form of surveys in which the authors assessed what lines of work might be profitable in their particular field, and what they might involve in facilities and training. For example, Dr. D. I. Page, of the CENTO Institute, considered the application of isotopes to water-flow problems, with special reference to conditions in Turkey. He listed ten problems which had been proposed by the Hydraulics Research Laboratories in Ankara. Of these, four appeared impracticable for such reasons as the large amount of radioactivity involved; two others appeared of doubtful feasibility; and four others, estimation of suspended matter in flood water, detection of seepage points in irrigation channels, movement of underground water, and analysis of cement by radioactivation, were worth pursuing.

Another paper providing useful guidance to countries considering new programmes was that on mutation-breeding in agriculture, by Dr. H. J. Curtis of the Brookhaven National Laboratory. $\mathrm{He}$ emphasized the necessity of growing very large numbers of plants in such work; the fact that the variations produced by radiation can also be produced by more conventional means; the need for a lengthy programme of orthodox plant-breeding before a commercially valuable variety can be derived from a radiation-produced mutant; and the meagre results to date in terms of new commercial varieties. Nevertheless, the fundamental aspects of the work fully justify continued effort.
Further papers in the same category were those on prospecting for radioactive minerals, on running a fall-out laboratory, on the use of carbon-14 in biochemistry, and on establishing a medical radioisotope clinic. There were also general discussions on the potentialities of radioisotope applications in the CENTO region, on their applications in the oil industry, and on atomic energy and public health.

Iran, as the host country, naturally sent the strongest delegation to the symposium, and this gave an opportunity for direct discussion of her nuclear science programme. Prof. A. A. Azad, who is in charge of the Tehran University Nuclear Centre, gave a general account of the programme, which includes a 5-MW. swimming-pool type reactor to be operating in 1962 ; and Dr. A. A. Sheibani described the Iranian radioactive prospecting project. The discussion which followed ranged over such fundamental issues as the possible uses of a large research reactor, and the value to the region of some of the larger nuclear instruments. The interest aroused was such that both the Pakistani and Turkish delegations expressed a desire for similar international discussions in their own countries.

Other topics at the symposium included reactor instrumentation, waste disposal and recent applications of radioisotopes in medicine, besides various research reports on nuclear physics and on applications of radioisotopes in botany and entomology.

The ohoice of Hamadan, a quiet, historic town, as the venue of the symposium, rather than Tehran, was something of a novelty to the Iranians, but was much appreciated by all the delegates on account of the relaxed atmosphere and opportunities for informal contacts that it provided. The local authorities contributed to this by their welcome and by their generosity in providing a meeting place, excursions and other amenities. As a final charming gift they gave each delegate a framed picture of a soientist of former days, Avicenna, whose home town was Hamadan.

H. A. C. MoKay

\section{CONVECTION IN METEOROLOGY}

T THE subject of "Convection" was chosen as the topic of the symposium for the first day of the Royal Meteorological Society's summer meeting held in the Electrical Engineering Department, Queen's College, Dundee, on June 30. This was the first meeting of the Society ever to be held in Dundee, and was to be followed on the next day by a symposium on "Agricultural Meteorology" (see Nature, $187,995 ; 1960)$. The president of the Society, Dr. J. M. Stagg, took the chair.

The opening speaker was Dr. F. H. Ludlam of the Imperial College of Science and Technology who reviewed the subject of convection in the atmosphere. This is a phenomenon which ranges in scale from the currents associated with fair-weather cumulus to those in the large thunderstorms which result in extensive flooding. Whereas the dynamics of the smaller currents are broadly understood as circulations associated with rising bubbles or columns of warm air, the dynamics of thunderstorms, or for that matter, the precise physical processes involved, are not so well understood. The Bénard convection cell pattern, for which a theory exists, does not seem to occur frequently in the atmosphere, although recent photographic evidence from an American weather research rocket shows a regular pattern of 'groups' of cumulus. The most satisfactory method of forecasting the extent of cumulus development still seems to be that based on the old 'parcel' theory, where the air is assumed to form into bubbles or 'parcels', which break away from the surface and rise adiabatically through the environment until a layer sufficiently stable to prevent further penetration is reached. This method entirely neglects any modification of the environment, such as subsidence warming, and leads to little real understanding of the dynamies of the process.

The difference between a large cumulus extending to, say, $15,000 \mathrm{ft}$., and a cumulonimbus, with its associated characteristics of hail and lightning, seems 